\title{
The genus Potamolithus Pilsbry, 1896 (Gastropoda: Tateidae) on the Somuncurá Plateau, Patagonia, Argentina
}

\author{
Micaela de Lucía ${ }^{a}$ and Diego Eduardo Gutiérrez Gregoric ${ }^{a, b}$ \\ ${ }^{a}$ División Zoología Invertebrados, Facultad de Ciencias Naturales y Museo, Universidad Nacional de La Plata, La Plata, Argentina; ${ }^{\text {bCConsejo }}$ \\ Nacional de Investigaciones Científicas y Técnicas (CONICET), La Plata, Argentina
}

\section{ABSTRACT}

The genus Potamolithus (Gastropoda: Tateidae) is endemic to South America where it is distributed mainly in the Ribeira, Itajaí-açú and Jacuhy Rivers in southern Brazil and the Uruguay River, part of the Paraná and Río de la Plata drainage systems. An exception to the pattern of distribution is Potamolithus valchetensis Miquel, 1998, which is endemic to the Valcheta Stream, Somuncurá Plateau, Patagonia, Argentina. Here we provide a review of Potamolithus from this plateau based on new samples and review of material deposited in collections. A new species, Potamolithus elenae, is named. The shell, head-foot, penis, pallial organs and radula are described. Differences between the new species and $P$. valchetensis include details in the shell, radula, body pigmentation and penis. A phylogeny using mitochondrial gene cytochrome $c$ oxidase subunit $I$ is provided which shows that Potamolithus is related to species in New Caledonia (Australasia), suggesting that the Tateidae has a Gondwanan distribution.

\section{ARTICLE HISTORY}

Received 17 August 2016

Final version received 22

December 2016

\section{KEYWORDS}

Anatomy; COI; conchology; endemic; freshwater snails;

Gondwanan distribution taxonomy

\section{Introduction}

At the southern end of South America freshwater gastropods are mostly represented by two families, Chilinidae (with about 50 species) and Tateidae (38 species) (Pons Da Silva 2003; Valdovinos Zarges 2006; Gutiérrez Gregoric and de Lucía 2016). The latter family is represented by the endemic genus Potamolithus Pilsbry, 1896 (Gastropoda: Tateidae) mainly present in the rivers of the Del Plata basin, Parana, Uruguay and Río de la Plata rivers in southern Brazil, Uruguay, Paraguay and Argentina (López Armengol 1985). Studies of species of the genus Potamolithus have been neglected despite their presence in the Uruguay and Río de la Plata rivers being largely responsible for these areas being considered biodiversity hotspots for freshwater gastropods (Strong et al. 2008). Most of the species of Potamolithus are known only from their shells. The few which have been studied anatomically are: P. agapetus Pilsbry, 1911; P. buschii (Frauenfeld, 1865); P. catharinae Pilsbry, 1911; P. karsticus Simone \& Moracchioli, 1994; P. lapidum (d'Orbigny, 1835); P. paranensis (Pilsbry, 1911); P. ribeirensis Pilsbry, 1911; P. rushii Pilsbry, 1896; P. simplex (Pilsbry, 1911); P. troglobius Simone \& Moracchioli, 1994 and P. valchetensis Miquel, 1998 (Pilsbry 1911; Davis and Pons Da Silva 1984; López Armengol 1985, 1996; Simone and Moracchioli 1994; Miquel 1998; Pons Da Silva and Veitenheimer-Mendes 2004; Núñez 2016).

Concerning their distribution, only two species have been mentioned outside the Del Plata basin:
Potamolithus australis Biese, 1944 in southern Chile, which is considered a dubious species as the description is based only on the holotype (shell and operculum) which was found in a lentic environment (López Armengol 1985); and $P$. valchetensis, which is endemic to the Valcheta Stream of Somuncurá Plateau, Río Negro province, Patagonia, Argentina. The latter species was based on samples recovered from the stomach of Gymnocharacinus bergi Steindachner, 1903 (Pisces: Characidae), and has not been subsequently collected. The description of $P$. valchetensis is based on shell and radular characters and a brief account of some pallial organs.

Somuncurá Plateau is a basaltic plain with an approximate area of $29,000 \mathrm{~km}^{2}$, and is located in the central region of the provinces of Río Negro and Chubut (Muzón et al. 2005). On the surface there are numerous aquatic environments (streams and lakes) some permanent and others temporary, only present following rainfall. In the province of Río Negro this area is a Provincial Reserve, mainly protecting the Valcheta Stream. This stream is an internal drainage basin formed after the union of two branches, known as 'Cold' and 'Hot', because the temperature of its waters ranges from $21^{\circ} \mathrm{C}$ to $22{ }^{\circ} \mathrm{C}$ and $22{ }^{\circ} \mathrm{C}$ to $26^{\circ} \mathrm{C}$, respectively (Wegrzyn et al. 1992). The Valcheta Stream follows a SO-NE direction, flowing through the villages of Valcheta and Chanquín, with a total length of c. $75 \mathrm{~km}$ culminating in the low Valcheta forming the Curicó Lagoon, which is an internal 
drainage system. This area is of great importance due to the existence of endemic species of vertebrates such as: Gymnocharacinus bergii, Pleurodema somuncurensis (Cei, 1969); Atelognathus reverberii (Cei, 1969); Lagidium viscacia somuncurensis (Crespo, 1963); Phymaturus somuncurensis (Cei \& Castro, 1973); Liolaemus ruizleali (Donoso Barros \& Cei, 1971); L. elongatus petrophilus (Donoso Barros \& Cei, 1971); and the caenogastropods Heleobia rionegrina (Gaillard, 1974) and Potamolithus valchetensis (Cei 1969; Bettinelli and Chebez 1986; Ortubay and Cussac 2000; Rumi et al. 2008).

Based on new samples in the basin of the Valcheta Stream, the objective of this work is to comment on the description of Potamolithus valchetensis and to describe a new species, Potamolithus elenae, based on shell, anatomy, and radula and some molecular data.

\section{Materials and methods}

Potamolithus valchetensis type material, deposited in the Museo Argentino de Ciencias Naturales 'Bernandino Rivadavia' (MACN 34011, 34012 and 34013) was examined. Samples from the Valcheta Stream were obtained in 2015 and were deposited in the Malacological Collection at the Museo de La Plata of the La Plata National University, Buenos Aires Province, Argentina (MLP-Ma). These specimens were examined under a Leica MZ6 stereoscopic microscope and drawn with the aid of camera lucida. Shell analysis was based on Hershler and Landye (1988) and Núñez (2016). The number of whorls was counted according to Parodiz (1951). The shells were drawn and photographed in apical, umbilical, ventral, lateral and dorsal views in order to make further measurements. All measurements given were taken from the drawings and represented in millimetres. Two specimens were placed

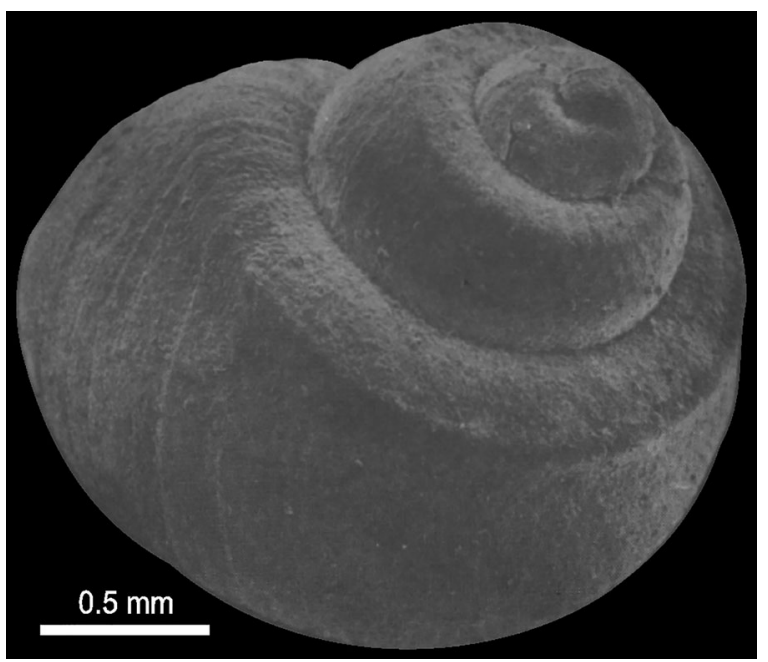

Figure 1. Potamolithus valchetensis. From Miquel (1998) with permission. in Railliet-Henry solution (distilled water 93\%, acetic acid $2 \%$, formalin $5 \%$ and $6 \mathrm{~g}$ of sodium chloride per $\mathrm{L}$ of solution) (Paraense 1976), to dissolve the shell. Length of the body, head, penis, ctenidium and osphradium were measured, and the colour described, according to Davis et al. (1986), Hershler and Landye (1988) and Hershler and Ponder (1998). We followed Davis et al. (1986) for radular measurements and Hershler and Ponder (1998) for descriptions of the teeth. A radula, two opercula and a shell were photographed using a scanning electron microscope (SEM) (JEOL/ JSMT 6360 LV, Tokyo, Japan) at MLP. In addition, DNA was extracted from two specimens and mitochondrial gene cytochrome c oxidase subunit I (COI) was amplified. A partial sequence of $\mathrm{COI}$ was amplified by the polymerase chain reaction ( $P C R)$ with the universal primers of Folmer et al. (1994). Amplification was performed in a final volume of $50 \mu \mathrm{L}$, following Gutiérrez Gregoric et al. $(2013,2014)$. The PCR products were purified with a Highway ADN PuriPrep-GP Kit (INBIO, Tandil City, Argentina) and both DNA strands were then directly cycle-sequenced (Macrogen Inc., Seoul, Korea). The resulting sequences were trimmed to remove the primers, and the consensus sequences of the individuals were compared to reference sequences in GenBank. The sequence alignment was performed with Clustal X 2.0.12 (Larkin et al. 2007), optimised by visual inspection and edited with a word processor. Phylogenetic analyses were undertaken comparing gene sequences from this study and related sequences in GenBank. Ascorhis tasmanica Martens, 1858 was used as the outgroup. The phylogenetic analyses were performed by using maximum likelihood (ML) and Bayesian inference (BI). A phylogenetic tree was constructed using the $\mathrm{ML}$ method based on the Tamura-Nei model (Tamura and Nei 1993). The bootstrap consensus tree inferred from 1000 replicates is taken to represent the evolutionary history of the taxa analysed (Felsenstein 1985). The initial tree for the heuristic search was obtained by applying the neighbor-joining method to a matrix of pairwise distances estimated using the maximum composite likelihood (MCL) approach. The analysis involved 34 nucleotide sequences. There was a total of 639 positions in the final dataset. Evolutionary analyses were conducted in MEGA6 (Tamura et al. 2013). The BI was carried out with the MrBayes 3.2 software (Ronquist et al. 2012). Two runs were performed simultaneously with four Markov chains that went for 1,000,000 generations, sampling every 100 generations.

\section{Results \\ Potamolithus valchetensis Miquel, 1998}

(Figure 1)

Potamolithus valchetensis Miquel 1998: 145-157, figs 2-9. 
Type material and type locality. Zoilo Chico stream, largest tributary of Valcheta, Río Negro province, Argentina, 1993, coll. S. Ortubay.

\section{Material examined}

Type material. Holotype: MACN 34011 (one specimen preserved in ethanol). Paratypes: MACN 34012: Zoilo Chico stream, largest tributary of Valcheta, Río Negro province, 1993, coll. S. Ortubay (two specimens in ethanol) and MACN 34013: Asconape stream, minor tributary of Valcheta, Río Negro province, 1993, coll. S. Ortubay (10 specimens in ethanol). The radula could not be revised as it is not deposited in the collection.

\section{Diagnosis}

Very small, shell trochoid, thick, light brown. Four whorls convex, with strong spiral keel at shoulder in upper part of whorl. Gill filaments triangular, few in number and poorly developed. Osphradium ovoid, small. Penis lacking lobe.

\section{Description}

Total length $2.00-2.53 \mathrm{~mm}$; total width1.87-2.13 mm; aperture length 1.20-1.47 mm; aperture width 0.80 $1.07 \mathrm{~mm}$. Shell trochoid, thick, whorls convex; periostracum light brown; with 3.50 to 4.25 whorls. Last whorl $80 \%$ of total length, narrow shoulder with strong keel. Spire low, with blunt apex. Sculptured with distinct axial ribs and growth striations. Sutures deeply impressed. Aperture oval, with continuous peristome. Outer lip thin, not reflected, with moderate basal expansion; columella thick, curved, dark brown and excavated with deep furrow. Umbilicus absent. Operculum corneous, paucispiral. Cephalic tentacles digitiform. Gill with few (number not specified and could not be determined from type material) small, triangular filaments, osphradium small. Penis long, cylindrical, with sharp end, surrounded by preputial ring, attached to the left of the midline of the neck. Females with nuchal node. Radula with central tooth having 9 (4-1-4) upper and 3 basal cups on each side; lateral tooth with 9 (4-1-4) cusps; inner marginal teeth with 25 cusps and outer marginal with 30 cusps.

\section{Remarks}

The material deposited in the MACN, including the type material, was originally preserved in formaldehyde and then transferred to ethanol. Unfortunately, the shells were decalcified, the radula was not available for examination and the body was in poor condition. Thus it was not possible to obtain new data to expand the original description. The length and width of the median cusp on the central tooth (longitude $4.37 \mu \mathrm{m}$, width $1.87 \mu \mathrm{m}$ ) were obtained using the published figures of the radula in the original work. The penis is attached to the left of the midline of the neck, similar to the New Caledonian tateid genera Hemistomia Crosse, 1872 and Leiorhagium Haase \& Bouchet, 1998 (Haase and Zielske 2015).

Potamolithus elenae de Lucía \& Gutiérrez Gregoric n. sp.

(Figures 2-4)

Type material and type locality. Thermal spring at Chipauquil, Valcheta Stream, Río Negro Province, Argentina, $\left(40^{\circ} 59^{\prime} 26.59^{\prime \prime} \mathrm{S}, 66^{\circ} 40^{\prime} 44.33^{\prime \prime} \mathrm{W}\right)$, coll. M. Velasco, 2015.

Holotype. MLP-Ma 14202.

Paratypes. MLP-Ma 14191, same data (three dry specimens - two radulae and one shell, two specimens in Railliet-Henry solution and one in ethanol).

\section{Diagnosis}

Shell up to $1.2 \mathrm{~mm}$ size, trochoid, thin, light brown, with weak spiral keel on shoulder, visible only on last whorl; 5-8 gill filaments; mid-ventral lobe on penis.

\section{Description}

Shell trochoid, thin, light brown, very small, wider than long (length $0.89-1.18 \mathrm{~mm}$, width $0.92-1.39 \mathrm{~mm}$ ), with 3.09 to 3.61 whorls (Figure $2 \mathrm{~A}-\mathrm{E}$; Table 1). Last whorl large ( $91 \%$ of total length), with weak spiral keel bordering narrow shoulder; spire low $(9 \%$ of total length), with blunt apex. Sculpture of rather weak axial ribs. Suture moderately impressed. Aperture oval, large (69\% of total length), with continuous peristome; outer lip simple. Columella thick, flat, light brown, width $0.21-0.29 \mathrm{~mm}$. Aperture prosocline, inclined $29^{\circ}$. Operculum corneous, light brown, elliptical, spiral, with submarginal nucleus, paucispiral, fills aperture when retracted, about 3 whorls (Figure 2F).

Radula of medium size ( $33 \%$ of total shell length), length $0.375 \mathrm{~mm}$, width $0.05 \mathrm{~mm}$, total rows teeth 80 , 4 rows teeth forming. Central tooth trapezoidal, dorsally concave, basal cusps arise from tooth face and larger than those on cutting edge. Width of base of central tooth $0.013 \mathrm{~mm}$, top width of central tooth $0.009 \mathrm{~mm}$. Central tooth with median cusp well-developed (length $3.45 \mu \mathrm{m}$, width $1.25 \mu \mathrm{m}$ ), pointed, 2/3 longer than other lateral cusps (Figure $3 \mathrm{~A}$ ). Lateral teeth with main cusp well-developed (length $5 \mu \mathrm{m}$, width $1.56 \mu \mathrm{m})$, pointed. Marginal teeth long, slightly curved, with pointed ends. Cusps on inner marginal teeth longer and wider than those on outer marginals (Figure 3B). Radular formula: central teeth (5-6)-1-(56), 2 left and 3 right basal cusps; lateral teeth with 10 to 11 cusps; inner marginal teeth with 20 to 25 cusps; outer marginal teeth with 25 to 29 (Table 2).

Head-foot with heavily pigmented head and snout, bluish-black, except on lips; snout wider than long 

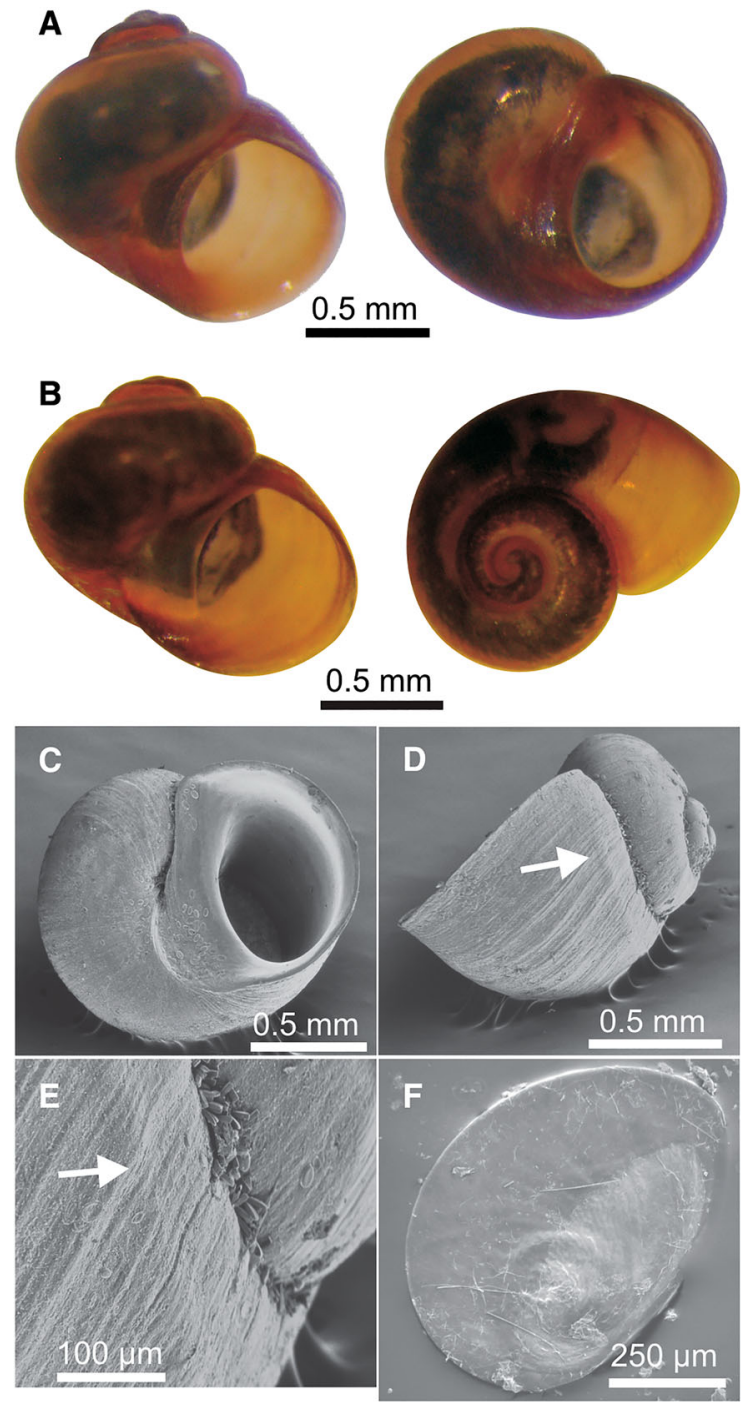

Figure 2. Potamolithus elenae n. sp. A, Holotype MLP-Ma 14202; B-E, Paratypes MLP-Ma 14191; F, operculum. The arrow indicates the keel at the edge of the shoulder.

with strong distal lobes (Figure 4A-B). Tentacles with unpigmented band distal to eyes, darkly pigmented with unpigmented distal ends. Above eyes pigmented

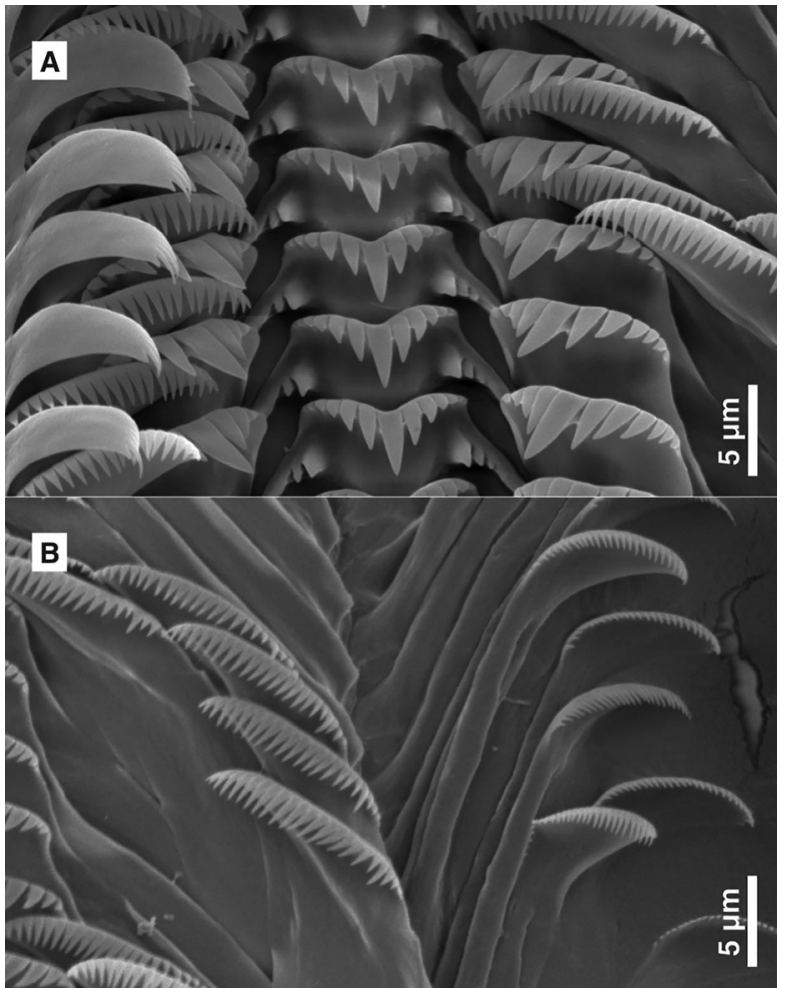

Figure 3. Radula of Potamolithus elenae n. sp. (MLP-Ma 14191 specimen 1). A, Detail of central, lateral and inner marginal teeth; B, inner and outer marginal teeth.

but below eyes small unpigmented area. Eye lobes weakly developed. Mantle roof and visceral coil bluish-black. Mantle cavity with reduced ctenidium comprised of about 5 to 8 filaments, and occupies $21 \%$ of visceral mass length. Osphradium oval, opposite posterior part of ctenidium, occupies $32 \%$ of ctenidium length. Anus near the edge of mantle on right side (Figure 4C). Penis occupies $21 \%$ of visceral mass length, with pigmentation in the mid-dorsal region, lobe in mid-ventral region and terminal papilla surrounded by the preputial ring (Figure 4D-E); distal end blunt. Distance between base of penis and eye

Table 1. Range (R), mean and standard deviation (SD) of shell measurements ( $\mathrm{mm}$ ) and ratios of Potamolithus elenae.

\begin{tabular}{|c|c|c|c|c|c|c|c|c|}
\hline & \multirow[b]{2}{*}{ Holotype } & \multicolumn{4}{|c|}{ Paratypes } & \multicolumn{3}{|c|}{ Total (Holotype + Paratypes) } \\
\hline & & No. of snails analysed & $\mathrm{R}$ & Mean & SD & $\mathrm{R}$ & Mean & SD \\
\hline NW & 3.35 & 6 & $3.09-3.61$ & 3.34 & 0.21 & $3.09-3.61$ & 3.34 & 0.19 \\
\hline $\mathrm{TL}$ & 1.18 & 6 & $0.89-1.18$ & 1.08 & 0.11 & $0.89-1.18$ & 1.09 & 0.11 \\
\hline LS & 0.13 & 6 & $0.08-0.13$ & 0.10 & 0.02 & $0.08-0.13$ & 0.10 & 0.02 \\
\hline LBW & 1.05 & 6 & $0.79-1.10$ & 0.98 & 0.12 & $0.79-1.10$ & 0.99 & 0.11 \\
\hline SB & 0.39 & 6 & $0.32-0.4$ & 0.35 & 0.03 & $0.32-0.40$ & 0.36 & 0.03 \\
\hline TW & 1.16 & 6 & $0.92-1.39$ & 1.18 & 0.15 & $0.92-1.39$ & 1.18 & 0.14 \\
\hline MWBW & 1.05 & 6 & $0.84-1.29$ & 1.12 & 0.16 & $0.84-1.29$ & 1.11 & 0.15 \\
\hline LA & 0.79 & 5 & $0.71-0.87$ & 0.77 & 0.06 & $0.71-0.87$ & 0.77 & 0.06 \\
\hline WA & 0.58 & 5 & $0.55-0.63$ & 0.58 & 0.03 & $0.55-0.63$ & 0.58 & 0.03 \\
\hline CW & 0.18 & 5 & $0.21-0.29$ & 0.24 & 0.03 & $0.21-0.29$ & 0.23 & 0.04 \\
\hline IA & 34 & 2 & $20-34$ & 27.00 & 9.90 & $20-34$ & 29.33 & 8.08 \\
\hline $\mathrm{LS} / \mathrm{TL}$ & 0.11 & 6 & $0.07-0.12$ & 0.09 & 0.02 & $0.07-0.12$ & 0.09 & 0.02 \\
\hline SB/LS & 3.00 & 6 & $2.92-4.25$ & 3.80 & 0.53 & $2.92-4.25$ & 3.69 & 0.57 \\
\hline SB/TW & 0.33 & 6 & $0.27-0.45$ & 0.33 & 0.07 & $0.27-0.45$ & 0.33 & 0.06 \\
\hline TL/TW & 1.02 & 6 & $0.85-0.98$ & 0.91 & 0.05 & $0.58-1.02$ & 0.93 & 0.06 \\
\hline $\mathrm{LA} / \mathrm{TL}$ & 0.67 & 5 & $0.63-0.74$ & 0.69 & 0.04 & $0.63-0.74$ & 0.69 & 0.04 \\
\hline LBW/TL & 0.89 & 6 & $0.88-0.93$ & 0.91 & 0.02 & $0.88-0.93$ & 0.91 & 0.02 \\
\hline
\end{tabular}

SB — spire base; CW — columella width; IA—inclination of the aperture; LA—length of aperture; LBW—length of body whorl; LS—length of spire; MWBWmedium width of body whorl; NW—no. of whorls; SB—-spire base; TL—-total length; TW—-total width; WA—width of aperture. 
Table 2. Radular formula of one radula of Potamolithus elenae.

\begin{tabular}{lcl}
\hline Tooth & $\begin{array}{c}\text { No. of teeth } \\
\text { analysed }\end{array}$ & \multicolumn{1}{c}{ Formula (\%) } \\
\hline Central & 14 & $\begin{array}{l}5-1-5(57.14) ; \\
(14.30) \\
2-3 \quad 2-3 \quad 2-5\end{array} \quad 2-3$ \\
Lateral & & $5-1-4$ \\
$\quad$ Left & 4 & $5-1-5(66.67) ; 4-1-6$ (33.33) \\
$\quad$ Right & 12 & $20-25$ \\
$\begin{array}{c}\text { Inner } \\
\text { marginal }\end{array}$ & 14 & $25-29$ \\
$\begin{array}{c}\text { Outer } \\
\text { marginal }\end{array}$ & 6 & \\
\hline
\end{tabular}


Figure 4. Potamolithus elenae n. sp. A, Pigmentation of the body; B, pigmentation pattern of the head and location of the penis; C, schematic diagram of mantle cavity structures; $\mathbf{D}$, penis detail in ventral view; $\mathbf{E}$, schematic diagram of penis detail in right ventrallateral view. c-ctenidium; ey-eye; i-intestine; lo-lobe mb-mantle border; os—osphradium; pa-terminal papilla; pepenis; $\mathrm{pr}$-preputial ring; sn-snout; tn-tentacle. 
Table 3. Range (R), mean and standard deviation (SD) of organs of the mantle cavity and penis measurements $(\mathrm{mm})$ of Potamolithus elenae $(n=2)$.

\begin{tabular}{lrrr}
\hline & \multicolumn{1}{c}{ R } & Mean & SD \\
\hline Ctenidium length (CL) & $0.33-0.50$ & 0.42 & 0.12 \\
Ctenidium width & $0.04-0.07$ & 0.07 & 0.06 \\
Osphradium length (OL) & $0.09-0.18$ & 0.14 & 0.06 \\
Osphradium width & $0.03-0.10$ & 0.07 & 0.05 \\
Width of mantle border (WMB) & $0.03-0.04$ & 0.04 & 0.01 \\
Gill filament No. & $5.00-8.00$ & 6.50 & 2.12 \\
Mantle cavity length (MCL) & $0.34-0.57$ & 0.46 & 0.16 \\
Visceral mass length (VML) & $2.39-2.55$ & 2.47 & 0.11 \\
WMB/MCL (\%) & $4.56-11.76$ & 8.16 & 5.09 \\
OL/CL (\%) & $30.00-32.73$ & 31.37 & 1.93 \\
CL/VML (\%) & $12.94-20.92$ & 16.93 & 5.64 \\
Penis length (PL) & $0.50-0.53$ & 0.52 & 0.02 \\
Medium width of penis & $0.10-0.11$ & 0.10 & 0.004 \\
Width of the terminal end of penis & $0.05-0.09$ & 0.07 & 0.028 \\
Width of the base of penis & $0.18-0.23$ & 0.21 & 0.04 \\
Maximum width of penis (MWP) & $0.18-0.23$ & 0.21 & 0.04 \\
Papilla length (PaL) & 0.079 & 0.08 & 0.00 \\
MWP/PL (\%) & $36.00-43.39$ & 39.70 & 5.23 \\
PL/VML (\%) & $20.78-20.92$ & 20.85 & 0.10 \\
PaL/PL (\%) & $14.90-15.80$ & 15.35 & 0.64
\end{tabular}

\section{Remarks}

This species is smaller in size than $P$. valchetensis, and are mature adults given the well-developed penis

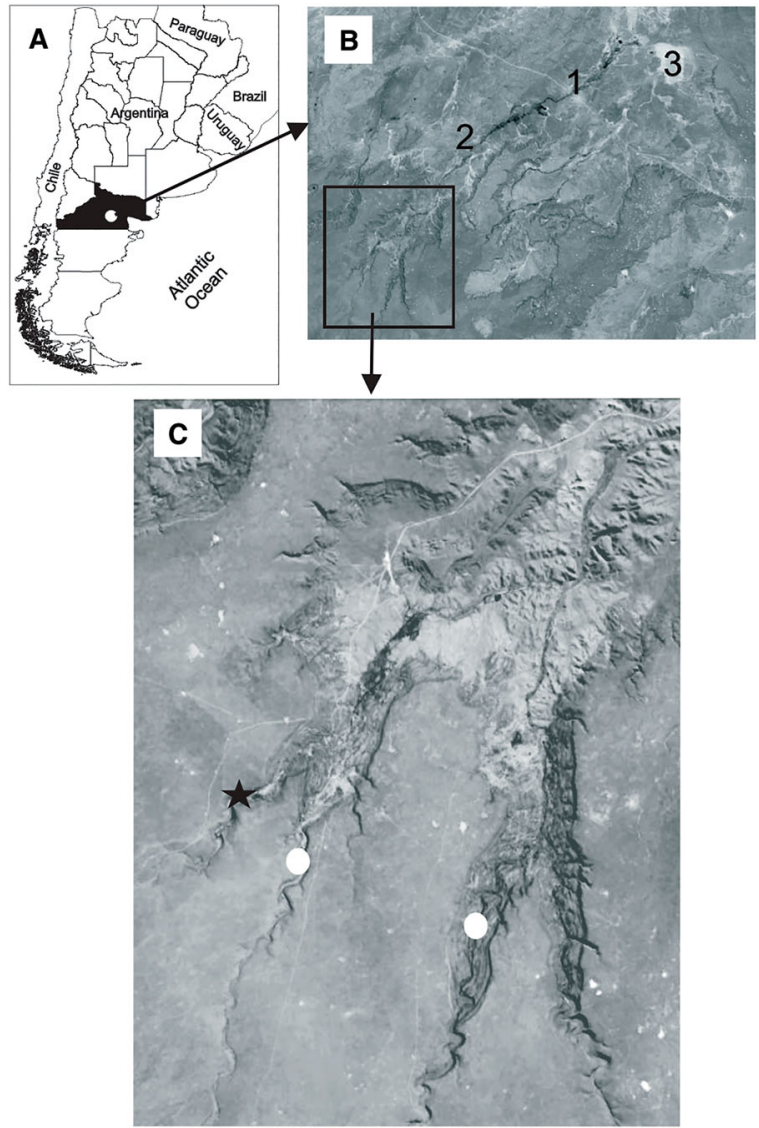

Figure 5. Map showing the type locality of Potamolithus elenae $\mathrm{n}$. sp. and the locality of Potamolithus valchetensis. A, Map of southern South America; B, Valcheta Stream basin; C, collection sites. 1, Valcheta city; 2, Valcheta Stream; 3, Curicó lagoon. $\star$-Potamolithus elenae; O-Potamolithus valchetensis.
Table 4. Taxon, collection locality data, reference and GenBank Accession Numbers for specimens analysed in this study.

\begin{tabular}{|c|c|c|c|}
\hline Taxon & Locality & Reference & GenBank \\
\hline $\begin{array}{l}\text { Ascorhis tasmanica } \\
\text { (Martens, 1858) }\end{array}$ & Australia & $\begin{array}{l}\text { Hershler et al. } \\
\text { (1999) }\end{array}$ & AF129329 \\
\hline $\begin{array}{l}\text { Beddomeia krybetes } \\
\quad \text { Ponder \& Clark, } 1993\end{array}$ & Australia & $\begin{array}{l}\text { Zielske et al. } \\
\text { (2017) }\end{array}$ & KT313292 \\
\hline $\begin{array}{l}\text { Beddomeia paludinella } \\
\quad \text { (Reeve, 1857) }\end{array}$ & Australia & $\begin{array}{l}\text { Wilke et al. } \\
\qquad(2013)\end{array}$ & JX970603 \\
\hline $\begin{array}{l}\text { Crosseana fallax (Haase \& } \\
\text { Bouchet, 1998) }\end{array}$ & $\begin{array}{l}\text { New } \\
\text { Caledonia }\end{array}$ & $\begin{array}{l}\text { Zielske and } \\
\text { Haase } \\
(2015)\end{array}$ & KJ490909 \\
\hline $\begin{array}{l}\text { Fluviopupa daunivucu } \\
\text { Haase, Ponder \& } \\
\text { Bouchet, } 2006\end{array}$ & Fiji & $\begin{array}{l}\text { Zielske and } \\
\text { Haase } \\
\text { (2014) }\end{array}$ & KF939813 \\
\hline $\begin{array}{l}\text { Halopyrgus pupoides } \\
\text { (Hutton, 1882) }\end{array}$ & New Zealand & Haase (2005) & AY631118 \\
\hline $\begin{array}{l}\text { 'Heleobia' hatcheri } \\
\text { (Pilsbry, 1911) }\end{array}$ & $\begin{array}{l}\text { San Juan, } \\
\text { Argentina }\end{array}$ & $\begin{array}{l}\text { Koch et al. } \\
(2015)\end{array}$ & KM220905 \\
\hline $\begin{array}{l}\text { Heleobia kuesteri (Strobel, } \\
\text { 1874) }\end{array}$ & $\begin{array}{l}\text { Mendoza, } \\
\text { Argentina }\end{array}$ & $\begin{array}{l}\text { Koch et al. } \\
\text { (2015) }\end{array}$ & KM220904 \\
\hline $\begin{array}{l}\text { Heleobia parchappii } \\
\text { (d'Orbigny, 1835) }\end{array}$ & $\begin{array}{l}\text { Mar Chiquita, } \\
\text { Argentina }\end{array}$ & $\begin{array}{l}\text { Kroll et al. } \\
\text { (2012) }\end{array}$ & JQ972709 \\
\hline $\begin{array}{l}\text { Heleobia piscium } \\
\text { (d'Orbigny, 1835) }\end{array}$ & $\begin{array}{l}\text { Buenos Aires, } \\
\text { Argentina }\end{array}$ & $\begin{array}{l}\text { Koch et al. } \\
\text { (2015) }\end{array}$ & KM220906 \\
\hline 'Heleobia' sp. & $\begin{array}{l}\text { Mendoza, } \\
\text { Argentina }\end{array}$ & $\begin{array}{l}\text { Koch et al. } \\
\text { (2015) }\end{array}$ & KM220908 \\
\hline $\begin{array}{l}\text { Heleobia umbiculata } \\
\text { (Haas, 1955) }\end{array}$ & Bolivia & $\begin{array}{l}\text { Kroll et al. } \\
(2012)\end{array}$ & JQ973053 \\
\hline $\begin{array}{l}\text { Hemistomia andreae } \\
\text { Haase \& Zielske, } 2015\end{array}$ & $\begin{array}{l}\text { New } \\
\text { Caledonia }\end{array}$ & $\begin{array}{l}\text { Zielske and } \\
\text { Haase } \\
(2015)\end{array}$ & KJ490851 \\
\hline $\begin{array}{l}\text { Hemistomia eclima Haase } \\
\quad \& \text { Bouchet, } 1998\end{array}$ & $\begin{array}{l}\text { New } \\
\text { Caledonia }\end{array}$ & $\begin{array}{l}\text { Zielske and } \\
\text { Haase } \\
(2015)\end{array}$ & KJ490859 \\
\hline $\begin{array}{l}\text { Hemistomia fabrorum } \\
\text { Haase \& Bouchet, } 1998\end{array}$ & $\begin{array}{l}\text { New } \\
\text { Caledonia }\end{array}$ & $\begin{array}{l}\text { Zielske and } \\
\text { Haase } \\
(2015)\end{array}$ & KJ490841 \\
\hline $\begin{array}{l}\text { Hemistomia minor Haase } \\
\quad \& \text { Bouchet, } 1998\end{array}$ & $\begin{array}{l}\text { New } \\
\text { Caledonia }\end{array}$ & $\begin{array}{l}\text { Zielske and } \\
\text { Haase } \\
(2015)\end{array}$ & KJ490831 \\
\hline $\begin{array}{l}\text { Hemistomia oxychila } \\
\text { Haase \& Bouchet, } 1998\end{array}$ & $\begin{array}{l}\text { New } \\
\text { Caledonia }\end{array}$ & $\begin{array}{l}\text { Zielske and } \\
\text { Haase } \\
(2015)\end{array}$ & KJ490894 \\
\hline $\begin{array}{l}\text { Leiorhagium inplicatum } \\
\quad \text { Haase \& Bouchet, } 1998\end{array}$ & $\begin{array}{l}\text { New } \\
\text { Caledonia }\end{array}$ & $\begin{array}{l}\text { Zielske and } \\
\text { Haase } \\
(2015)\end{array}$ & KJ490845 \\
\hline $\begin{array}{l}\text { Leptopyrgus tainui Haase, } \\
2008\end{array}$ & New Zealand & Haase (2005) & AY631078 \\
\hline $\begin{array}{l}\text { Meridiopyrgus muaukau } \\
\text { Haase, } 2008\end{array}$ & New Zealand & Haase (2005) & AY631083 \\
\hline $\begin{array}{l}\text { Meridiopyrgus murihiku } \\
\text { Haase, } 2008\end{array}$ & New Zealand & Haase (2005) & AY631084 \\
\hline $\begin{array}{l}\text { Obtusopyrgus alpinus } \\
\text { Haase, } 2008\end{array}$ & New Zealand & Haase (2005) & AY631089 \\
\hline $\begin{array}{l}\text { Opacuincola } \\
\text { johannstraussi Haase, } \\
2008\end{array}$ & New Zealand & Haase (2005) & AY631094 \\
\hline $\begin{array}{l}\text { Opacuincola josefstraussi } \\
\text { Haase, } 2008\end{array}$ & New Zealand & Haase (2005) & AY631096 \\
\hline $\begin{array}{l}\text { Opacuincola permutata } \\
\text { Haase, } 2008\end{array}$ & New Zealand & Haase (2005) & AY631100 \\
\hline $\begin{array}{l}\text { Potamolithus agapetus } \\
\text { Pilsbry, } 1911\end{array}$ & $\begin{array}{l}\text { Buenos Aires, } \\
\text { Argentina }\end{array}$ & $\begin{array}{l}\text { Koch et al. } \\
\text { (2015) }\end{array}$ & KM220910 \\
\hline $\begin{array}{l}\text { Potamolithus buschii } \\
\text { (Frauenfeld, 1865) }\end{array}$ & $\begin{array}{l}\text { Buenos Aires, } \\
\text { Argentina }\end{array}$ & $\begin{array}{l}\text { Koch et al. } \\
(2015)\end{array}$ & KM220909 \\
\hline $\begin{array}{l}\text { Potamolithus elenae de } \\
\text { Lucía \& Gutiérrez } \\
\text { Gregoric, } 2016\end{array}$ & $\begin{array}{l}\text { Valcheta } \\
\text { Stream, } \\
\text { Argentina }\end{array}$ & This study & $\begin{array}{l}\text { KX397599; } \\
\text { KX397600 }\end{array}$ \\
\hline $\begin{array}{l}\text { Potamolithus lapidum } \\
\text { supersulcatus Pilsbry, } \\
1896\end{array}$ & $\begin{array}{l}\text { Uruguay River, } \\
\text { Argentina. }\end{array}$ & This study & KX158843 \\
\hline $\begin{array}{l}\text { Potamolithus ribeirensis } \\
\text { Pilsbry, } 1911\end{array}$ & $\begin{array}{l}\text { Sao Paulo, } \\
\text { Brazil }\end{array}$ & $\begin{array}{l}\text { Wilke et al. } \\
\text { (2013) }\end{array}$ & JX970618 \\
\hline $\begin{array}{l}\text { Potamopyrgus } \\
\text { antipodarum (Gray, } \\
1843 \text { ) }\end{array}$ & New Zealand & $\begin{array}{l}\text { Neiman et al. } \\
(2010)\end{array}$ & GQ996429 \\
\hline $\begin{array}{l}\text { Tatea huonensis (Tenison- } \\
\text { Woods, 1876) }\end{array}$ & Australia & $\begin{array}{l}\text { Colgan \& da } \\
\text { Costa }(*)\end{array}$ & FJ619824 \\
\hline $\begin{array}{l}\text { Tatea rufilabris (Adams, } \\
\text { 1862) }\end{array}$ & Australia & Golding $(*)$ & KC439802 \\
\hline
\end{tabular}


Table 5. Pairwise genetic divergence (Kimura two-parameter, \%) among species of Potamolithus and two species of 'Heleobia' assessed by means of $\mathrm{COI}$ gene sequences. The new species is highlighted in bold.

\begin{tabular}{|c|c|c|c|c|c|c|}
\hline & 1 & 2 & 3 & 4 & 5 & 6 \\
\hline \multicolumn{7}{|l|}{ 1. 'Heleobia' hatcheri } \\
\hline 2. 'Heleobia' sp. & 8.53 & & & & & \\
\hline $\begin{array}{l}\text { 3. Potamolithus } \\
\text { elenae }\end{array}$ & 9.62 & 7.85 & & & & \\
\hline 4. Potamolithus buschii & 12.08 & 10.24 & 7.34 & & & \\
\hline $\begin{array}{l}\text { 5. Potamolithus } \\
\text { lapidum } \\
\text { supersulcatus }\end{array}$ & 12.26 & 8.93 & 8.97 & 6.81 & & \\
\hline $\begin{array}{l}\text { 6. Potamolithus } \\
\text { agapetus }\end{array}$ & 12.91 & 9.88 & 9.16 & 7.91 & 8.08 & \\
\hline $\begin{array}{l}\text { 7. Potamolithus } \\
\text { ribeirensis }\end{array}$ & 13.77 & 11.16 & 10.61 & 11.72 & 12.09 & 11.70 \\
\hline
\end{tabular}

and apertural development. The new species differs from $P$. valchetensis in the following additional characters. Thin shell (vs. thick), fewer number of whorls (3.34 vs. 4), LT/TW ratio smaller (93 vs. 110) and LBW/LT larger (91 vs. 80), shoulder keel weaker; columella flat without groove (with groove in $P$. valchetensis); the radula has more cusps on the central teeth (12 vs. 9), basal cusps asymmetrical (2-3) vs. symmetrical (3-3), and the median cusp is triangular with a pointed end (vs. parallel edges and blunt end) and is smaller (length $3.45 \mu \mathrm{m}$ vs. $4.37 \mu \mathrm{m}$, width $1.25 \mu \mathrm{m}$ vs. $1.87 \mu \mathrm{m})$; the lateral teeth have more cusps (10-11 vs. 9) and the main cusp is shaped like an isosceles triangle (vs. parallel edges and blunt end). In the penis of the material examined there is a lobe in the mid-ventral region (not present in $P$. valchetensis), and there is a terminal papilla protruding from the blunt distal end (pointed distal end in $P$. valchetensis). The penis is pigmented in the mid-dorsal region (this feature is not mentioned in P. valchetensis). Also, the penis is triangular in appearance, with wide base and attached to the middle of the right neck area while in $P$. valchetensis it is cylindrical, maintaining a uniform thickness from its base to the prepuce ring. No females were observed in the material analysed. Compared to the

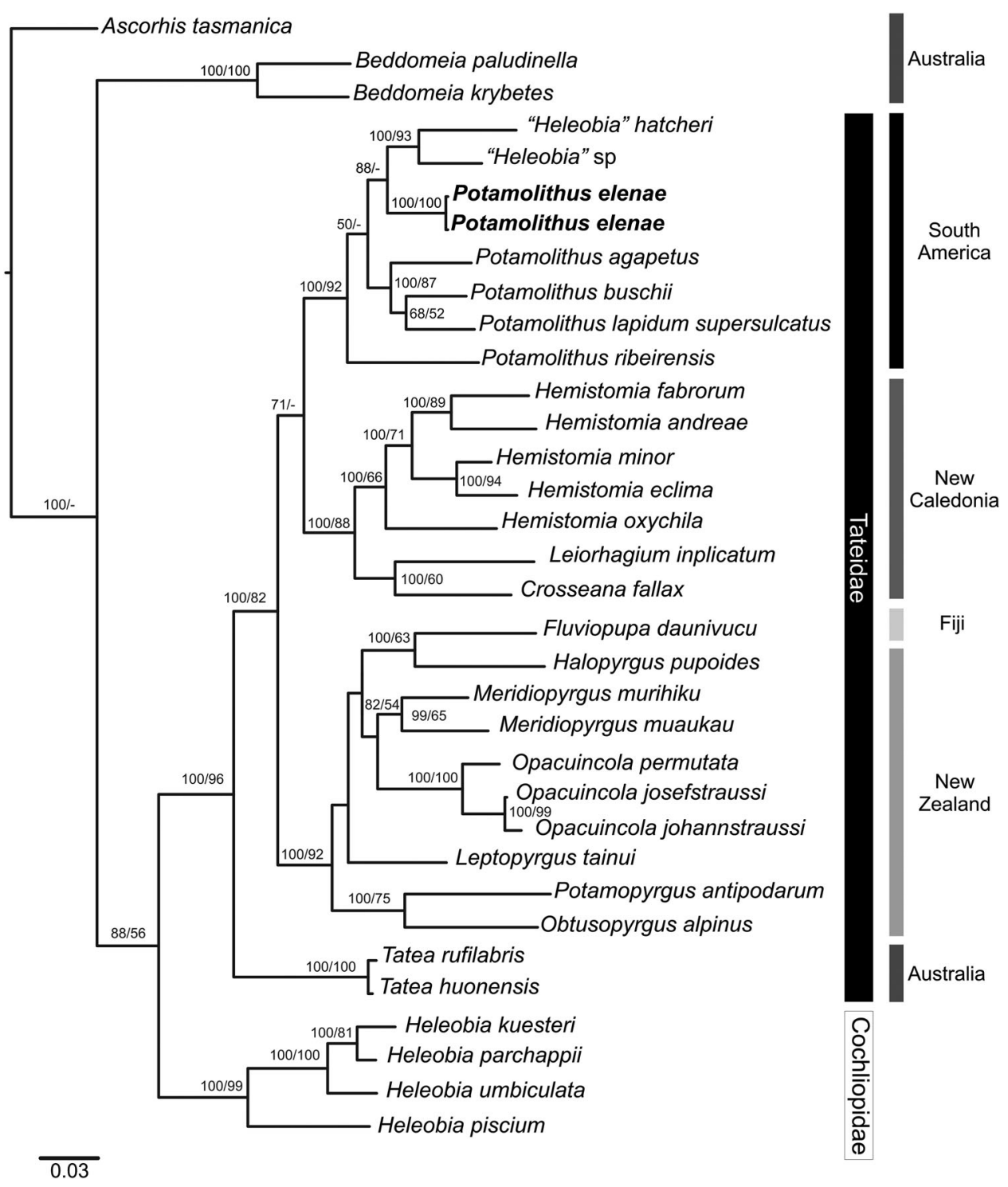

Figure 6. Bayesian consensus tree based on a $639 \mathrm{pb}$ fragment of the $\mathrm{COI}$ gene. Bayesian posterior probabilities and bootstrap values (\%) are shown (BI/ML). Values lower than $50 \%$ are not shown. The new species is highlighted in bold. 
cavernicolous Brazilian species, $P$. karsticus and $P$. troglobius, described by Simone and Moracchioli (1994), which are also of small size, $P$. elenae is smaller (1.03-1.18 $\mathrm{mm}$ vs. $1.9-2.5 \mathrm{~mm})$, with a wider shell (vs. shells longer than wide) and has fewer gill filaments (5-8 vs. 10-12). The head is heavily pigmented, while $P$. karsticus has a brown pigmentation with dark spots behind the eyes and around the dorsal sagittal line, and $P$. troglobius is light yellow in colour. In addition, $P$. elenae has well-developed eyes and eye lobes are weakly developed, while $P$. karsticus has eyes without eye lobes and $P$. troglobius has no eyes or eye lobes. Potamolithus paranensis (Pilsbry, 1911), redescribed by Núñez (2016), has a small lateral lobe at the junction of the base and the terminal part (2.94\% of penis length), while the lobe in $P$. elenae is at $15 \%$ of the penis length and is located mid-ventrally. Potamolithus elenae has a terminal penial papilla, as do $P$. agapetus, $P$. buschii, P. lapidum supersulcatus Pilsbry, $1896, P$. ribeirensis and $P$. valchetensis (Davis and Pons Da Silva 1984; López Armengol 1996; Miquel 1998; de Lucía, pers. obs.). This terminal papilla is surrounded by a preputial ring as observed in $P$. lapidum supersulcatus, $P$. ribeirensis and $P$. valchetensis (Davis and Pons Da Silva 1984; Miquel 1998; de Lucía, pers. obs.).

\section{Etymology}

Dedicated to the grandmother, Elena, of the first author of this paper.

\section{Molecular analysis}

The length of the $\mathrm{COI}$ sequences for $P$. elenae was $659 \mathrm{bp}$ while $P$. lapidum supersulcatus was $658 \mathrm{pb}$ and $P$. agapetus, $P$. buschii, $P$. ribeirensis, 'Heleobia' hatcheri (Pilsbry, 1911) and 'Heleobia' sp. were all 638 pb (Table 4). There is a gap in both sequences of $P$. elenae in location 629. The genetic distance in the COI gene with the other species found in South America is higher than $6.8 \%$ (Table 5). The phylogenetic trees obtained by ML and BI methods show a similar topology differing only in minor details (Figure 6). Potamolithus elenae is more closely related to 'Heleobia' sp. and 'Heleobia' hatcheri, both present in south central Argentina. On the other hand, the species in the Del Plata basin constitute another clade within the genus Potamolithus. Potamolithus ribeirensis from the Iporanga River basin, Brazil, is basal in Potamolithus in our analysis. Of the taxa in the analysis, the South American tateid clade is more closely related to the New Caledonian genera than those found in Fiji and New Zealand, and even less related to the few Australian taxa included.

\section{Discussion}

Phylogenetic analyses confirm that the South American taxa included are members of the Tateidae, namely the species of Potamolithus and two species attributed to the cochliopid genus Heleobia Stimpson, 1865 ('Heleobia' sp. and 'Heleobia' hatcheri), already mentioned by Koch et al. (2015). 'Heleobia' hatcheri is a parthenogenetic species and has similarities in radular morphology (two or three pairs of basal cusps in the central tooth) as in species of Potamolithus and which are absent in typical species of Heleobia (Cochliopidae) in Argentina (Cazzaniga 2011; Koch et al. 2015). 'Heleobia' sp. and 'Heleobia' hatcheri are known only from females, but in our study of Potamolithus elenae we did not find females for comparison. The two taxa previously attributed to Heleobia clearly do not belong to Cochliopidae, and the generic status of these species will be discussed elsewhere (E. Koch, pers. comm., 2016). The Cochliopidae family is a well-defined clade being quite distinct from Tateidae (Wilke et al. 2013; Koch et al. 2015). Reproductive characters (morphology of the penis, prostate gland, as well as female characters) are considered of importance in defining tateid genera, but due to the small size of the samples, and because the specimens were not relaxed prior to fixation, it was not possible to make a more detailed anatomical study of the reproductive system.

The Valcheta Stream has distinctive habitat and faunistic characteristics compared to other Patagonian basins, so it was excluded from the malacological provinces of North and South Patagonia defined by Núñez et al. (2010). This new species, Potamolithus elenae, enhances the conservation status of the Somuncurá Plateau, now a reserve (Protected Natural Area, Somuncurá Plateau). However, the level of protection is insufficient, mainly due to overgrazing, poaching, removal of individuals, modification of waterways, water pollution and introduced species (Muzón et al. 2005; Anonymous 2007).

\section{Acknowledgements}

We thank Melina Velasco and Federico Kacoliris for the donation of material and the staff of the malacological collection of the Museo Argentino de Ciencias Naturales 'Bernardino Rivadavia' (MACN) for their generosity in allowing review of the type of Potamolithus valchetensis material. We thank Sergio Miquel for the authorisation of Figure 1. We are grateful to Prof. Emma Galatti for English editing. We are especially grateful to Dr. Winston F. Ponder whose critical reading and comments helped improve this manuscript.

\section{Disclosure statement}

No potential conflict of interest was reported by the authors.

\section{References}

Anonymous. (2007) Plan de Manejo Área Natural Protegida Meseta de Somuncurá Provincia de Río Negro. Programa de Apoyo a la Modernización Productiva de la Provincia de Río Negro. Universidad Nacional de Comahue. 
Bettinelli, M.D. \& Chebez, J.C. (1986) Notas sobre aves de la meseta de Somuncurá, Río Negro, Argentina. Hornero 12, 230-234.

Cazzaniga, N.J. (2011) Heleobia Stimpson, 1865: Taxonomía. In: Cazzaniga N.J. (Ed), El género Heleobia (Caenogastropoda: Cochliopidae) en América del Sur. Amici Molluscarum (número especial), 12-17.

Cei, J.M. (1969) The patagonian telmatobiid fauna of the volcanic Somuncura Plateau of Argentina. Journal of Herpetology 3, 1-18.

Davis, G.M. \& Pons Da Silva, M.C. (1984) Potamolithus: morphology, convergence, and relationships among hydrobioid snails. Malacologia 25, 73-108.

Davis, G.M., Rao, N.S. \& Hoagland, K.E. (1986) In search of Tricula (Gastropoda: Prosobranchia): Tricula defined, and a new genus described. Proceedings of the Academy of Natural Sciences of Philadelphia 138, 426-442.

Felsenstein, J. (1985) Confidence limits on phylogenies: an approach using the bootstrap. Evolution 39, 783-791.

Folmer, O., Black, M., Hoeh, W., Lutz, R. \& Vrijenhoek, R. (1994) DNA primers for amplification of mitochondrial cytochrome C oxidase subunit I from diverse metazoan invertebrates. Molecular Marine Biology and Biotechnology 3, 294-299.

Gutiérrez Gregoric, D.E. \& de Lucía, M. (2016) Freshwater gastropods diversity hotspots: three new species from the Uruguay River (South America). PeerJ 4, e2138.

Gutiérrez Gregoric, D.E., Beltramino, A., Vogler, R.E., Cuezzo, M.G., Núñez, V., Gómez, S., Virgillito, M. \& Miquel, S.E. (2013) First records of four exotic slugs in Argentina. American Malacological Bulletin 31, 245-256.

Gutiérrez Gregoric, D.E., Ciocco, N.F. \& Rumi, A. (2014) Two new species of Chilina Gray from Cuyo Malacological Province, Argentina (Gastropoda: Hygrophila: Chilinidae). Molluscan Research 34, 84-97.

Haase, M. (2005) Rapid and convergent evolution of parental care in hydrobiid gastropods from New Zealand. Journal of Evolutionary Biology 18, 1076-1086.

Haase, M. \& Zielske, S. (2015) Five new cryptic freshwater gastropod species from New Caledonia (Caenogastropoda, Truncatelloidea, Tateidae). ZooKeys 523, 63-87.

Hershler, R. \& Landye, J.J. (1988) Arizona Hydrobiidae. Smithsonian Contributions to Zoology 459, 1-63.

Hershler, R. \& Ponder, W.F. (1998) A review of morphological characters of hydrobioid snails. Smithsonian Contributions to Zoology 600, 1-55.

Hershler, R., Liu, H.P. \& Mulvey, M. (1999) Phylogenetic relationships within the aquatic snail genus Tryonia: implications for biogeography of the North American southwest. Molecular Phylogenetics and Evolution 13, 377-391.

Koch, E., Martín, S.M. \& Ciocco, N.F. (2015) A molecular contribution to the controversial taxonomical status of some freshwater snails (Caenogastropoda: Rissooidea, Cochliopidae) from the Central Andes desert to Patagonia. Iheringia. Série Zoologia 105, 69-75.

Kroll, O., Hershler, R., Albrecht, C., Terrazas, E.M., Apaza, R., Fuentealba, C. \& Wilke, T. (2012) The endemic gastropod fauna of Lake Titicaca: correlation between molecular evolution and hydrographic history. Ecology and Evolution 2, 1517-1530.

Larkin, M.A., Blackshields, G., Brown, N.P., Chenna, R., McGettigan, P.A., McWilliam, H., Valentin, F., Wallace, I.M., Wilm, A., Lopez, R., Thompson, J.D., Gibson, T.J. \& Higgins, D.G. (2007) Clustal $W$ and Clustal $X$ version 2.0. Bioinformatics 23, 2947-2948.

López Armengol, M.F. (1985) Estudio sistemático y bioecológico del género Potamolithus (Hydrobiidae) utilizando técnicas de taxonomía numérica. Doctoral thesis $\mathrm{N}^{\circ}$
455, Facultad Ciencias Naturales y Museo, Universidad Nacional de La Plata, La Plata city, Argentina. 281 pp.

López Armengol, M.F. (1996) Taxonomic revision of Potamolithus agapetus Pilsbry, 1911, and Potamolithus buschii (Frauenfeld, 1865) (Gastropoda: Hydrobiidae). Malacologia 38, 1-17.

Miquel, S.E. (1998) A new species of Potamolithus from Patagonia (Gastropoda, Prosobranchia, Hydrobiidae). Biociências 6, 145-157.

Muzón, J., Spinelli, G.R., Pessacq, P., Von Ellenrieder, N., Estevez, A.L., Marino, P.I., Pérez Goodwyn, P.J., Angrisano, E.B., Díaz, F., Fernández, L.A., Mazzucconi, S., Rossi, G. \& Salomón, O.D. (2005) Insectos acuáticos de la Meseta del Somuncurá, Patagonia, Argentina. Inventario preliminar. Revista de la Sociedad Entomológica Argentina 64, 47-67.

Neiman, M., Hehman, G., Miller, J.T., Logsdon Jr., J.M. \& Taylor, D.R. (2010) Accelerated mutation accumulation in asexual lineages of a freshwater snail. Molecular Biology and Evolution 27, 954-963.

Núñez, V. (2016) Redescription of Potamolithus paranensis (Pilsbry, 1911) and Potamolithus simplex (Pilsbry, 1911) (Gastropoda: Tateidae). Molluscan Research. DOI: 10.1080/ 13235818.2016.1201038. (in press).

Núñez, V., Gutiérrez Gregoric, D.E. \& Rumi, A. (2010) Freshwater gastropod provinces from Argentina. Malacologia 53, 47-60.

Ortubay, S.G. \& Cussac, V.E. (2000) Threatened fishes of the world: Gymnocharacinus bergi Steindachner, 1903 (Characidae). Environmental Biology of Fishes 58, 144.

Paraense, L.W. (1976) Lymnaea viatrix: a study of topotypic specimens (Mollusca: Lymnaeidae). Revista Brasileira de Biologia 36, 419-428.

Parodiz, J.J. (1951) Métodos de conquiliometria. Physis 20, 241-248.

Pilsbry, H.A. (1911) Non-marine Mollusca of Patagonia. In: Scott, W.B. (Ed.), Reports of the Princeton University Expeditions to Patagonia, 1896-1899, Vol 3, Zoology, Part V. Princeton University, USA, Princeton, NJ, pp. 513-633.

Pons Da Silva, M.C. (2003) Hydrobiidae (Gastropoda, Neotaenioglossa, Rissooidea) da planície costeira do Rio Grande do Sul, Brasil. Tese de Doutorado em Biologia Animal, Instituto de Biociências da Universidade Federal do Rio Grande do Sul, Porto Alegre, Brasil.

Pons Da Silva, M.C. \& Veitenheimer-Mendes, I.L. (2004) Redescrição de Potamolithus catharinae com base em topotipos (Gastropoda, Hydrobiidae), rio Hercílio, Santa Catarina, Brasil. Iheringia Serie Zoologia 94, 83-88.

Ronquist, F., Teslenko, M., van der Mark, P., Ayres, D.L., Darling, A., Höhna, S., Larget, B., Liu, L., Suchard, M.A. \& Huelsenbeck, J.P. (2012) MrBayes 3.2: efficient Bayesian phylogenetic inference and model choice across a large model space. Systematic Biology 61, 539-542.

Rumi, A., Gutiérrez Gregoric, D.E., Núñez, V. \& Darrigran, G. (2008) Malacología Latinoamericana. Moluscos de agua dulce de Argentina. Revista de Biología Tropical 56, 77-111.

Simone, L.R.L. \& Moracchioli, N. (1994) Hydrobiidae (Gastropoda: Hydrobioidea) from the Ribeira valley, SE Brazil, with descriptions of two new cavernicolous species. Journal of Molluscan Studies 60, 445-459.

Strong, E.E., Gargominy, O., Ponder, W.F. \& Bouchet, P. (2008) Global diversity of gastropods (Gastropoda; Mollusca) in freshwater. Hydrobiologia 595, 149-166.

Tamura, K. \& Nei, M. (1993) Estimation of the number of nucleotide substitutions in the control region of mitochondrial DNA in humans and chimpanzees. Molecular Biology and Evolution 10, 512-526. 
Tamura, K., Stecher, G., Peterson, D., Filipski, A. \& Kumar, S. (2013) MEGA6: molecular evolutionary genetics analysis version 6.0. Molecular Biology and Evolution 30, 2725-2729.

Valdovinos Zarges, C. (2006) Estado de conocimiento de los gastrópodos dulceacuícolas de Chile. Gayana 70, 88-95.

Wegrzyn, D., Úbeda, C., Ortubay, S., Gil, M. \& Cúrtolo, L. (1992) Plan de manejo de la Cuenca del arroyo Valcheta. Parte 1: el recurso íctico. Dirección de Pesca, Subsecretaría de Recursos Naturales, Ministerio de Economía de Río Negro, Viedma. p. 61.

Wilke, T., Haase, M., Hershler, R., Liu, H.P., Misof, B. \& Ponder, W. (2013) Pushing short DNA fragments to the limit: phylogenetic relationships of 'hydrobioid' gastropods (Caenogastropoda: Rissooidea). Molecular Phylogenetics and Evolution 66, 715-736.
Zielske, S. \& Haase, M. (2014) New insights into tateid gastropods and their radiation on Fiji based on anatomical and molecular methods (Caenogastropoda: Truncatelloidea). Zoological Journal of the Linnean Society $172,71-102$.

Zielske, S. \& Haase, M. (2015) Molecular phylogeny and a modified approach of character-based barcoding refining the taxonomy of New Caledonian freshwater gastropods (Caenogastropoda, Truncatelloidea, Tateidae). Molecular Phylogenetics and Evolution 89, 171-181.

Zielske, S., Ponder, W.F. \& Haase, M. (2017) The enigmatic pattern of long-distance dispersal of minute freshwater gastropods (Caenogastropoda, Truncatelloidea, Tateidae) across the South Pacific. Journal of Biogeography 44, 195206. 